\title{
An Introduction to Shared-Use Commercial Kitchens ${ }^{1}$
}

\author{
Matthew Krug and Sarah Ellis ${ }^{2}$
}

\section{Background}

The number of shared-use commercial kitchen facilities in Florida and the United States has increased in recent years. Many food entrepreneurs utilize these facilities to launch or expand their food businesses as a way to save on initial cost of investment and avoid having to build their own facilities. There are several different names or definitions used to describe these operations, which may lead to confusion for entrepreneurs interested in using such facilities. This document intends to provide basic definitions of several types of shared-use commercial kitchens and include other relevant information about these facilities in Florida.

\section{What is a shared-use commercial kitchen?}

The term commercial kitchen describes facilities that are designed and built to current code and sanitary standards with running water, appropriate plumbing, and surfaces that are suitable for food production. These facilities must meet minimum construction standards in the food preparation and adjacent areas so that food business operators can comply with state or federal regulations when processing food. Shared-use commercial kitchens often have multiple food preparation areas, cold and dry storage, professionalgrade equipment, and an existing sanitation program so that multiple food businesses may operate simultaneously. Members can rent the existing infrastructure by hourly, daily, or monthly time blocks to establish and operate their food businesses (Meader McCausland et al. 2018).
Several terms are commonly used to describe shared-use commercial kitchens, such as incubator, accelerator, community kitchens, food hub, or food innovation centers. While these terms are nearly interchangeable, they may indicate subtle differences in kitchen model or objectives. Table 1 lists several definitions applicable to shared-use kitchen types.

\section{Food Regulations and Permits}

Regardless of the shared-use kitchen type, there is a common goal of allowing businesses to operate in compliance with applicable food safety regulations. In Florida, owners are required to register their food businesses with the Florida Department of Business and Professional Regulation (DBPR) or Florida Department of Agriculture and Consumer Services (FDACS) and are subject to initial and subsequent inspections. Common businesses regulated by DBPR include restaurants, caterers, and temporary event vendors, while FDACS regulates retail and wholesale food processors.

There are several food regulations applicable to businesses depending on the type of food, method of sale, and average amount of annual sales. Usually small food businesses are either required to follow the FDA Food Code or Current Good Manufacturing Practices (CGMPs) found in 21 CFR 117 at a minimum. Shared-use kitchens are likely to have several different businesses operating simultaneously, meaning that multiple regulations may be enforced, and inspections executed from multiple agencies (i.e., DBPR

1. This document is FSHN20-41, one of a series of the Food Science and Human Nutrition Department, UF/IFAS Extension. Original publication date September 2020. Visit the EDIS website at https://edis.ifas.ufl.edu for the currently supported version of this publication.

2. Matthew Krug, state specialized agent, food science, UF/IFAS Southwest Florida Research and Education Center, Immokalee, FL; and Sarah Ellis, Extension agent I, family and consumer sciences, UF/IFAS Extension Citrus County, Lecanto, FL.

The Institute of Food and Agricultural Sciences (IFAS) is an Equal Opportunity Institution authorized to provide research, educational information and other services

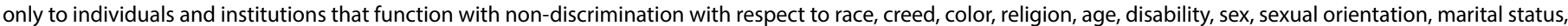

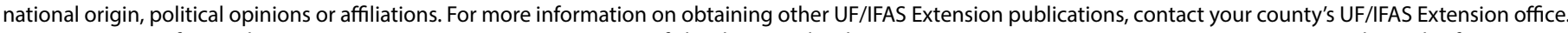
U.S. Department of Agriculture, UF/IFAS Extension Service, University of Florida, IFAS, Florida A \& M University Cooperative Extension Program, and Boards of County Commissioners Cooperating. Nick T. Place, dean for UF/IFAS Extension. 
and FDACS) within the same facility. Although shared-use kitchen owners may provide guidance, it is up to each individual business owner to obtain the necessary permitting so that their business may operate out of the facility.

\section{Additional Services}

Shared-use commercial kitchen owners or employees may provide additional services to members to guide them through the steps of opening and growing a food business. Potential opportunities include food-safety trainings, business classes, marketing and distribution opportunities, legal and financial advising, and packaging or branding services. Facilities may be owned or have a partnership with a university, which allows easy access for experts to implement these trainings or services (i.e., Extension education). Privately owned facilities may have the resources to provide these services or could rely upon outside sources (i.e., consultants). The level of guidance and services offered by each facility will depend on the needs of the clientele and the resources available.

The level of guidance and services offered will vary between facilities. However, this seems to be the best distinguishing factor between the facility types listed in Table 1, although the use of a term such as "accelerator" in the name of a facility does not always indicate they follow the model described in the definition. Some facilities only follow the basic commissary model, with the sole purpose of providing commercial kitchen space to interested business owners. This model could be adequate for someone with an established business whose limiting factor is the lack of commercial kitchen space. On the other hand, entrepreneurs in the beginning stages of operating a food business may rely upon the additional services an incubator, accelerator, or food hub provides.

While entrepreneurs are searching for a facility to house their food business, it is important for them to determine their needs, communicate with the facility owners or directors, and decide if their goals align with the resources the facility provides. Another item they should consider is whether the kitchen rental rates are within the financial means of their business. Facilities may rent out kitchen space in hourly, daily, or monthly blocks; entrepreneurs should select a facility that best meets the needs of their expected usage. Several shared-use commercial kitchens around Florida and the United States provide options to food entrepreneurs. A list of current shared-use commercial kitchen facilities in Florida is found in Table 2.

\section{Benefits of Using a Shared-Use Commercial Kitchen}

When starting a business, food entrepreneurs face several start-up costs, such as purchasing or building a facility, furnishing the facility with commercial equipment, supplying tools/utensils, and making down payments on utilities. The costs to build out a commercial kitchen in an existing space can run up to $\$ 100-\$ 300$ per square foot (Meader McCausland et al. 2018), which may be unworkable for clientele with limited financial means. Shared-use commercial kitchens can help reduce this financial burden for small food businesses.

Ultimately, shared-use facilities provide adequate commercial kitchen space, with minimal capital investment, so local food entrepreneurs may try out new products in the market and limit the effect of potential product failure. Furthermore, the resources, services, and networking opportunities these facilities may provide will ease the process of launching a new food business and may catalyze the growth of the business.

\section{Additional Resources FDACS}

Minimum Construction Standards: https://www.fdacs.gov/ content/download/64038/file/Food_Establishment_Minimum_Construction_Standards.pdf

Retail Food Permit Info: https://www.fdacs. gov/Business-Services/Food-Establishments/ Retail-Food-Establishment-Permit

Wholesale Food Permit Info: https://www.fdacs. gov/Business-Services/Food-Establishments/ Wholesale-Manufactured-Food-Establishment-Permit

\section{DBPR}

Food Service Permit Info: https://www.myfloridalicense. com/intentions2. asp?chBoard=true\&boardid=200\&SID $=$ 
Table 1. Shared-Use Commercial Kitchen Type Definitions

\begin{tabular}{|l|l|}
\hline Commissary & $\begin{array}{l}\text { An established commercial kitchen that allows food businesses to rent kitchen time to prepare and store food. } \\
\text { May also offer mobile food vendors a place to acquire potable water and dispose of wastewater. }\end{array}$ \\
\hline Incubator Kitchen & $\begin{array}{l}\text { An entrepreneurial support organization with commercial kitchen facilities focused on advancing the growth of } \\
\text { small and emerging food businesses. Often these facilities offer trainings or services to guide members as they } \\
\text { open and grow a small food business. }\end{array}$ \\
\hline Accelerator Kitchen & $\begin{array}{l}\text { Typically, a kitchen facility with a short-term program designed to help food businesses with high growth } \\
\text { potential. Members receive guidance and networking opportunities, and in return, the accelerator may obtain a } \\
\text { percentage of equity in the company. }\end{array}$ \\
\hline Community Kitchen & $\begin{array}{l}\text { A shared-use kitchen that serves the community at large and is not for the exclusive use of for-profit businesses. } \\
\text { May apply to kitchens found in facilities such as churches or community centers. }\end{array}$ \\
\hline Food Hub & $\begin{array}{l}\text { An aggregation and distribution center for locally produced foods. May include a shared-use kitchen for food } \\
\text { processing, but also a retail market (e.g., coffee shop) where clientele may sell their products. }\end{array}$ \\
\hline Food Innovation Center & $\begin{array}{l}\text { A multiprogram facility that offers technical services to entrepreneurs. May or may not include kitchen space for } \\
\text { rent. }\end{array}$ \\
\hline Definitions derived from AFDO (2017), Meader McCausland et al. (2018), and Topaloff (2014). \\
\hline
\end{tabular}

\section{References}

Association of Food and Drug Officials (AFDO). 2017.

"Guidelines for Incubator Kitchens." http://www.afdo.org/

resources/Documents/pubs/Guidelines-for-Incubator-

Kitchens.pdf. Accessed 26 Mar 2020.

Meader McCausland, D., R. Miller, A. Colpaart, and M.

King. 2018. Shared Kitchen Toolkit: A Practical Guide to

Planning, Launching and Managing a Shared-Use Commer-

cial Kitchen. The Food Corridor. http://www.thefoodcor-

ridor.com/resources/. Accessed 26 Mar 2020.

Topaloff, A. 2014. "The Shared-Use Kitchen Planning

Toolkit." Leopold Center Pubs and Papers. 33. http://lib.

dr.iastate.edu/leopold_pubspapers/33. 
Table 2. Shared-Use Commercial Kitchens in Florida

\begin{tabular}{|c|c|c|c|}
\hline Business Name & Location, City & Phone Number & Website \\
\hline Almendra's Kitchen & Orlando & $321-348-7386$ & www.almendraskitchen.com \\
\hline $\begin{array}{l}\text { Beaver Street } \\
\text { Commissary }\end{array}$ & Jacksonville & $904-655-6603$ & www.beaverstreetcommissary.com \\
\hline $\begin{array}{l}\text { Catapult Kitchen } \\
\text { Incubator }\end{array}$ & Lakeland & $863-940-9660$ & catapultlakeland.com/kitchen/ \\
\hline $\begin{array}{l}\text { Central Florida } \\
\text { Commissary }\end{array}$ & Oviedo & $407-917-1441$ & \\
\hline $\begin{array}{l}\text { Citrus County } \\
\text { Community Kitchen }\end{array}$ & Lecanto & $352-527-7540$ & $\begin{array}{l}\text { www.citrusbocc.com/departments/community_services/parks__recreation/ } \\
\text { community_building_rentals/community_kitchen.php }\end{array}$ \\
\hline $\begin{array}{l}\text { Commercial Kitchen } \\
\text { Fort Myers }\end{array}$ & Fort Myers & $239-462-3589$ & www.commercialkitchenfortmyers.com \\
\hline $\begin{array}{l}\text { Denise's } \\
\text { Commissary } \\
\text { Kitchen }\end{array}$ & Groveland & $863-236-8590$ & denisecommissarykitchen.business.site/ \\
\hline East End Market & Orlando & $321-236-3316$ & www.eastendmkt.com \\
\hline EZ Pro Kitchen & Tampa & 813-530-5776 & www.ezprokitchen.com \\
\hline $\begin{array}{l}\text { Florida Chefs } \\
\text { Workshop }\end{array}$ & St. Petersburg & 727-308-1256 & www.floridachefsworkshop.com \\
\hline $\begin{array}{l}\text { Florida Culinary } \\
\text { Accelerator @ } \\
\text { Immokalee }\end{array}$ & Immokalee & 239-249-5911 Ext.1 & www.theculinaryaccelerator.com \\
\hline Food Hub & Miami & 786-599-6484 & www.food-hub.co \\
\hline Green Leaf Kitchen & Longwood & $407-790-7825$ & www.greenleafkitchen.net \\
\hline $\begin{array}{l}\text { Healthy Food } \\
\text { Factory }\end{array}$ & Boca Raton & $561-394-7466$ & www.healthyfoodfactory.com/ \\
\hline Jax Kitchen & Jacksonville & $904-619-5872$ & www.jax-kitchen.com \\
\hline $\begin{array}{l}\text { Kissimmee Kitchen } \\
\text { Share }\end{array}$ & Kissimmee & $407-398-5245$ & \\
\hline KitchenSHARE & Tallahassee & 850-577-1615 & www.kitchensharetlh.com/ \\
\hline Let's Eat Fresh & Ocala & $352-299-5233$ & www.letseatfresh.net/ \\
\hline $\begin{array}{l}\text { Let's Cook Shared } \\
\text { Kitchen }\end{array}$ & Tampa & $813-260-4604$ & www.letscooksharedkitchen.com \\
\hline My-Rent-A-Kitchen & Clearwater & 813-376-9185 & www.myrentakitchen.com \\
\hline $\begin{array}{l}\text { Orlando Caterers \& } \\
\text { Commissary }\end{array}$ & Orlando & $407-745-5636$ & www.orlandoflcaterers.com \\
\hline $\begin{array}{l}\text { Pasco County One } \\
\text { Stop Shop }\end{array}$ & Dade City & $352-521-1254$ & www.pascocountyfl.net/3581/One-Stop-Shop---Incubator-Kitchen \\
\hline Prokitchen Hub & Tampa & $727-244-5368$ & www.prokitchenhubtampa.com \\
\hline Pro Kitchen Hub & Sunrise & $954-812-6698$ & www.prokitchenhub.com \\
\hline $\begin{array}{l}\text { Rise Commercial } \\
\text { Kitchen Share }\end{array}$ & Sarasota & & www.risekitchen.com/ \\
\hline $\begin{array}{l}\text { Something So } \\
\text { Yummy }\end{array}$ & Naples & $239-449-6068$ & commercialkitchennaples.com/ \\
\hline $\begin{array}{l}\text { StartUP FIU Food } \\
\text { Incubator }\end{array}$ & Miami & $305-348-7156$ & www.startup.fiu.edu/food/food-incubator/ \\
\hline Sunshine Kitchen & Fort Pierce & $772-247-2800$ & www.stlucieco.gov/departments-services/a-z/sunshine-kitchen \\
\hline Tampa Bay Kitchen & Tampa & $727-432-2317$ & www.tampabaykitchen.com/ \\
\hline The Kitchen 24 & Oldsmar & $727-940-2403$ & www.thekitchen24.com \\
\hline Working Food & Gainesville & $352-260-4458$ & www.workingfood.org \\
\hline $\begin{array}{l}\text { Your Culinary Place } \\
\text { LLC }\end{array}$ & Sarasota & $941-922-9222$ & www.yourculinaryplace.com \\
\hline
\end{tabular}

